\title{
Social-Media-Assisted Learning: A Case Study of Teaching Computer Science on Facebook
}

\author{
Pei-Yi Ku, Yu-Tzu Lin, Member, IEEE, and Yu-Hsin Tsai
}

\begin{abstract}
The rapid development of social media brings a new change to education: students can share information and discussion with colleagues to learn new knowledge. Since social learning theory claims that people construct their cognition from continuous reciprocal interaction in the social environment, it is interesting to investigate whether and how social media foster computer science learning. In this study, we discuss the influence of students' interaction on social media upon computer science learning by a case study of teaching computer science on Facebook. An experiment was conducted in the computer science class in a senior high school. Students were asked to discuss lecture topics with each other on Facebook in each class. The discussion issues need exploration and higher-level thinking. Both qualitative and quantitative analyses were applied to understand how social interaction affected computer science learning. We also applied techniques of social network analyses to mine more information of learners' behaviors. The experiment results show that students' learning attitude toward computer science was improved in a social-media-based environment. However, there was no significant difference in learning achievements between high-interaction and low-interaction groups. The major reason is that students need a clearer guide for discussion. Therefore, discussion guide strategies should be developed to prevent meaningless statements so that the discussion can be converged and then students can benefit more from social interaction on the social media.
\end{abstract}

Terms-Social media, facebook, social learning, computer science education, problem solving.

\section{INTRODUCTION}

With the rapid development of the Web 2.0 technologies, social media (e.g., Facebook, Twitter, and Wiki) develop rapidly and become more and more popular. The rise of social media brings new possibilities in many aspects, including education. Students can share and exchange resources, ideas, and product easily, and create more information together with others via social media. In order to understand how social media influences learning, some research [1] devoted to the study of analyzing learning/teaching behaviors in a social-media learning environment. Existing research [2] showed that integrating social media into the learning environment can be effective in increasing learners' satisfaction with the course, improving their learning and writing ability, and fostering learners' interaction. In some research, cooperative learning strategies

Manuscript received April 17, 2012; revised June 4, 2012.

The authors are with the Graduate Institute of Information and Computer Education, National Taiwan Normal University, Taiwan (e-mail: smile.peggy333@gmail.com, 699080085@ntnu.edu.tw). were applied to help students construct their knowledge via social interaction. Cho et al. [3] discussed the relationships among communication models, social network, and learning achievement in the community of computer supported collaborative learning (CSCL). They found that willingness to communicate is not relevant significantly to the role and position of CSCL network. Moreno et al. [4] employed Moodle to study how constructivism works in the CSCL environment.

The major goal of this CS curriculum is to develop students' problem solving ability, which is especially significant for programming [5]. Many researchers [6,7] considered the main goal of education as teaching students to think about learning subjects deeply by exploring, reasoning, analyzing, and applying techniques and knowledge to solve new problems. A good learner must have better analysis and judgment skills. However, it is not easy to teach students problem solving skills. In Yen and Lee's research [8], a blended methodology combining online and face-to-face teaching was employed to enhance students' problem solving skills. In the blended methodology, a cooperative learning strategy was introduced to foster students' thinking skills. In addition to the face to face lecture, students also used Facebook to discuss the learning topics. Their experiments proved the feasibility of blended learning. The study of Beck and Chizhik [9] indicated that females could benefit more from cooperative learning than males. Another research [10] discussed the quality of discussion on Facebook, in which the authors found that most discussions were off topic, but they were still valuable in knowledge construction.

Several existing works have discussed whether peer apprenticeship learning, web-based learning, or social learning affect computer science learning [11-13], but still very few works investigated whether and how social network affects computer science teaching and learning. Therefore, we are interested in whether and how social interaction activities in social media can improve computer science learning.

\section{RESEARCH METHODS}

\section{A. Participants}

The teaching experiment was carried out in three classes (Class-A: 46 boys, Class-B: 39 boys, Class-C: 24 girls and 8boys; Class-A and Class-B are Science class, Class-C is Liberal Arts class) in a downtown senior high school, which had a higher entrance examination grade than the national average. 


\section{B. Procedure}

The experiment lasted six weeks, and the teacher presented one project per week. Computer virus, cloud computing, sorting algorithms, and programming were included in the teaching content (See Table I). In each 50-minute class, teacher taught in a traditional lecture-based way for 15 to 20 minutes, and then students were asked to work on social learning exercises for 30 to 35 minutes. In the social learning exercises, students discussed class content and practice problems on Facebook. In the beginning, teacher informed students that their participation would affect their grades. Students can have several actions: posting an article, replying to one article, or "like" one article/comment. They were also encouraged to post articles related to the discussion topic and avoid meaningless ones.

TABLE I: LECTURE CONTENT AND DISCUSSION QUESTIONS

\begin{tabular}{|c|c|c|}
\hline Lecture Topic & Lecture Content & Discussion Questions \\
\hline $\begin{array}{l}\text { Computer } \\
\text { Virus }\end{array}$ & $\begin{array}{l}\text { 1. The history of } \\
\text { computer viruses } \\
\text { 2. Famous computer } \\
\text { virus creators } \\
\text { 3. Characteristics of } \\
\text { computer viruses } \\
\text { 4. The life cycle of the } \\
\text { computer virus }\end{array}$ & $\begin{array}{l}\text { 1. Discuss the existing } \\
\text { virus types, their } \\
\text { characteristics. } \\
\text { 2. Share the experiences of } \\
\text { getting computer } \\
\text { viruses (Why do you } \\
\text { get virus? What } \\
\text { damages were caused } \\
\text { by the virus) } \\
\text { 3. How to avoid getting the } \\
\text { computer virus? }\end{array}$ \\
\hline
\end{tabular}

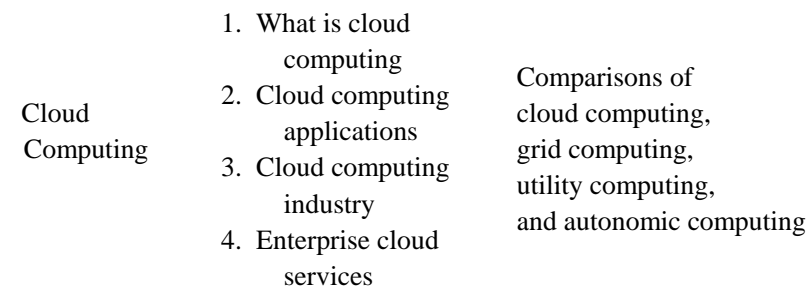

$\begin{array}{lll}\text { Sorting } & \text { How does the } & \begin{array}{l}\text { Find other sorting } \\ \text { algorithms, and }\end{array} \\ \text { Algorithms } & \text { Bubble sort work } & \begin{array}{l}\text { explain how they work } \\ \end{array}\end{array}$

$\begin{array}{ll}\begin{array}{l}\text { 1. If statement } \\ \text { 2. If...else... } \\ \text { statement }\end{array} & \begin{array}{c}\text { 1. A discussion of the } \\ \text { results after the } \\ \text { implementation of the } \\ \text { Programming }\end{array} \\ \begin{array}{l}\text { 3. If...else...if...else } \\ \text { statement }\end{array} & \begin{array}{c}\text { loop example } \\ \text { 4. For loop }\end{array} \\ \begin{array}{l}\text { 5. While loop } \\ \text { 2. Make the 1A2B game fl } \\ \text { ow chart }\end{array}\end{array}$

In order to understand students' initial behaviors, we conducted a pre-test of basic computer concepts before the experiment. All of questions are multiple choice questions. In this test, all classes had similar performances (as shown in Table II).

After three weeks, a midterm exam was conducted to see the changes after social learning for a period of time, of which the questions are: (1) Describe Trojan virus, (2)
Decribe cloud computing, and (3) Apply any sorting method to sort assigned numbers. All of the above questions were open questions. In the midterm exam, Class-A and Class-B had similar average scores (77.5 and 73.95), and Class-C had lower average score (58.71).

At the end of the experiment, we implemented a post-test. The purpose of the post-test was to test students about their basic concept of "for loop". True/False questions and blank filling questions were included in the post-test. The results of post-test were: Class-A had the average score of 52.5, Class-B had the average score of 55.95 points, and Class-C had the average score of 38.83 points. (see Table II)

TABLE II: THE PERFORMANCES OF TESTS.

\begin{tabular}{cccc}
\hline \hline Class & $\begin{array}{c}\text { PRE-TEST } \\
(\text { MEAN) }\end{array}$ & $\begin{array}{c}\text { MID-TEST } \\
\text { (MEAN) }\end{array}$ & $\begin{array}{c}\text { POST-TEST } \\
(\text { MEAN) }\end{array}$ \\
\hline Class-A & 87.34 & 77.5 & 52.5 \\
\hline Class-B & 82.13 & 73.95 & 55.95 \\
\hline Class-C & 83.26 & 58.71 & 38.83 \\
\hline \hline
\end{tabular}

In the class, the teacher spent 15-20 minutes teaching. After the teacher announced the topic, students took 30 to 35 minutes for discussion on Facebook. Students posted their ideas or information on group's wall. If anyone agreed with this opinion, he/she could give a "like" or comment. The teacher gave some brief explanation of what student did not understand and provided some hyperlinks so that students could find reference materials. Also, some questions were proposed in the teaching materials to make students think After the discussion, the teacher explained the unclear issues.

\section{Social Network Analysis}

To mine students' relations and behaviors more deeply, techniques of social network analysis was also employed. Social network [14], [15] uses nodes and links to describe the social structure, in which nodes represent individuals or organizations, and links are relationships between nodes. Social network can be used to illustrate various social relationships, e.g. friendship, relatives, financial transactions Social network analysis is to mine the possible social events by verifying nodes and links of the social network, which is widely employed in social and behavior science [16].

In this research, the discussion behavior was represented by a graph, as shown in Fig. 1. (a) shows the social communication among students, in which the direction of the arrow represents whether an action or relationship occurs between two students. The directed relations can be represented by an adjacency matrix, like Fig. 1(b).

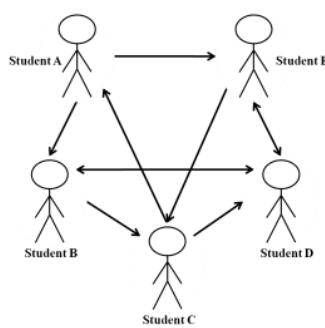

(a) 


\begin{tabular}{|c|c|c|c|c|c|}
\hline Student & A & B & C & D & E \\
\hline A & 0 & 1 & 0 & 0 & 1 \\
\hline B & 0 & 0 & 1 & 1 & 0 \\
\hline C & 1 & 0 & 0 & 1 & 0 \\
\hline D & 0 & 1 & 0 & 0 & 1 \\
\hline E & 0 & 0 & 1 & 1 & 0 \\
\hline
\end{tabular}

(b)

Fig. 1. The representation of the social network: (a) relations among students in the cooperative learning network, and (b) the corresponding adjacency matrix.

\section{EXPERIMENT RESULTS}

There were two research questions in this study: (a) Do higher interaction groups on social media have better performance than lower interaction groups? (b) Can the social-media-assisted learning enhance students' learning attitudes or performances? The correlation among the post frequency, the number of comments, and the changes of scores was computed to understand whether students posted more articles or provided more comments (i.e., had high interaction) had higher performances. However, the degree of interaction was not significantly related to the degree of achievement improvements based on the statistical results (see Table III). Students with more improvements on learning achievements were not the ones who posted more articles or comments (as shown in Fig. 2).

TABLE III: PARTICIPATION IN THE EXTENT AND PROGRESS OF THE DEGREE OF CORRELATION ANALYSIS.

\begin{tabular}{|c|c|c|c|c|}
\hline & & $\begin{array}{c}\text { Post } \\
\text { frequency }\end{array}$ & $\begin{array}{c}\text { \# of } \\
\text { comments }\end{array}$ & $\begin{array}{c}\text { Changes of } \\
\text { scores }\end{array}$ \\
\hline \multirow{3}{*}{$\begin{array}{c}\text { Post } \\
\text { frequency }\end{array}$} & $\begin{array}{c}\text { Pearson } \\
\text { correlation }\end{array}$ & 1 & $.656^{* *}$ & .146 \\
\hline & $\begin{array}{l}\text { Significant } \\
\text { two-tailed }\end{array}$ & & .000 & .351 \\
\hline & Number & 47 & 47 & 43 \\
\hline \multirow{3}{*}{$\begin{array}{c}\text { \# of } \\
\text { comments }\end{array}$} & $\begin{array}{c}\text { Pearson } \\
\text { correlation }\end{array}$ & $.656^{* * *}$ & 1 & .199 \\
\hline & $\begin{array}{l}\text { Significant } \\
\text { two-tailed }\end{array}$ & .000 & & .200 \\
\hline & Number & 477 & 47 & 43 \\
\hline \multirow{3}{*}{$\begin{array}{l}\text { Changes of } \\
\text { scores }\end{array}$} & $\begin{array}{c}\text { Pearson } \\
\text { correlation }\end{array}$ & .146 & .199 & 1 \\
\hline & $\begin{array}{l}\text { Significant } \\
\text { two-tailed }\end{array}$ & .351 & .200 & \\
\hline & Number & 43 & 43 & 45 \\
\hline
\end{tabular}

**.SIGNIFICANCE LEVEL OF 0.01(TWO-TAILED), SIGNIFICANT

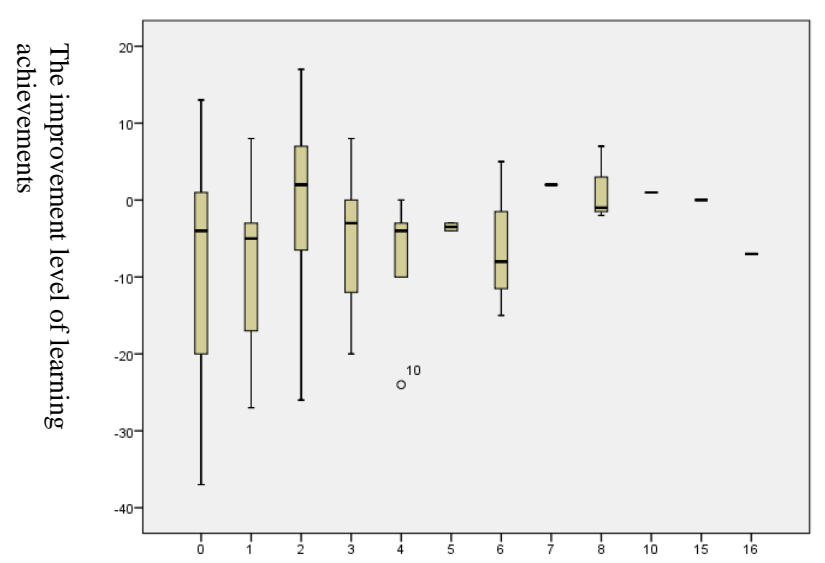

(b)

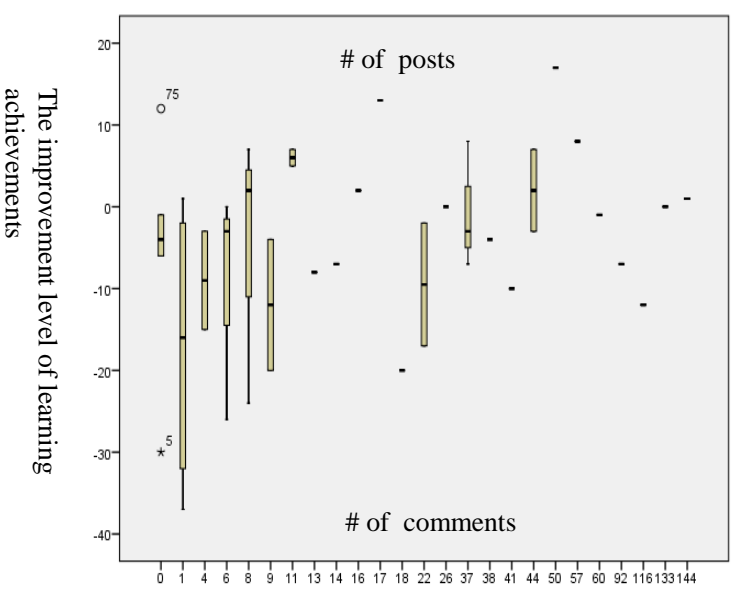

(b)

Fig. 2. The correlation between of the improvement levels of learning achievements and (a) the number of posts, or (b) the number of comments.

To understand whether students' social relations influence their learning behaviors, social network analysis was conducted to see the interaction frequencies among students (Fig. 3) and links among them (Fig. 4). However, the quantitative analysis also shows that relations among students were not correlated to their learning achievements.

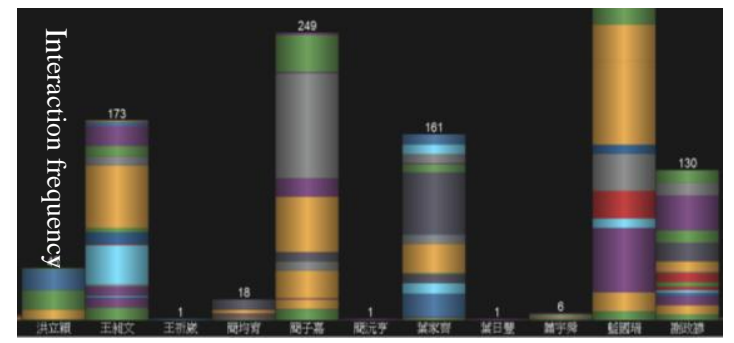

Fig. 3. The interaction Seglengiess among students.

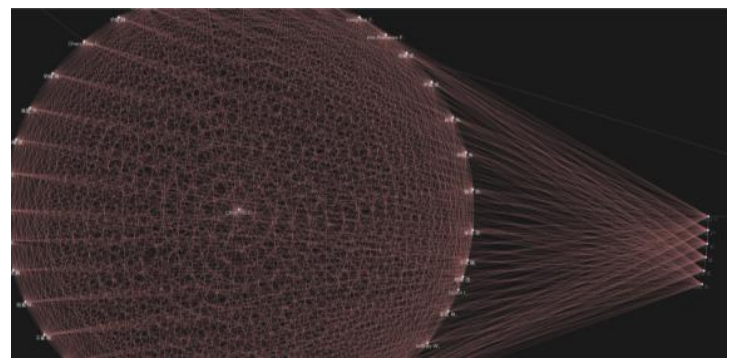

Fig. 4. The links among students.

In the questionnaire test, most students had positive attitude towards the social-media-assisted learning. They also had positive response in the open questions:

"Learning on Facebook is very interesting."

"Discussion on Facebook makes me feel more secure than face-to-face discussion."

"I can gather new information on Facebook easily."

The questionnaire results can be summarized into four issues: (a) some students said that they could not focus on lecture topics while using the Facebook. They could see so many irrelevant messages that they were distracted from the discussion issues. (b) Most of the students responded that learning on Facebook was very interesting, and it was very easy to raise questions immediately. So they preferred using Facebook or similar kinds of media for learning. One reason was that they could see others' performance in our additive interface (as shown in Fig. 5). (c) Students' prior knowledge 
needs to be understood so that the teachers can design suitable materials and guide strategies for them. And thus students can engage easily into discussions. To prevent "copy and paste", discussion questions should be designed appropriately.

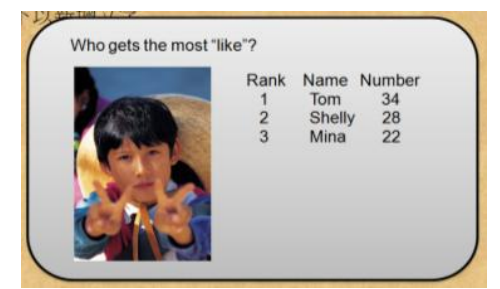

(a)

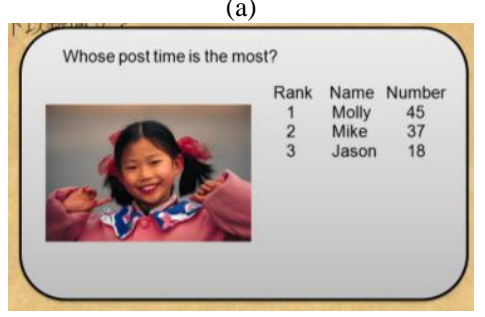

(b)

Fig. 5. Additive user interface for (a) teachers, and (b) students, in which they can see the ranking of students' interaction.

\section{CONCLUSIONS AND FutURE RESEARCH}

In this research, both qualitative and quantitative studies were conducted to investigate whether computer science learning was influenced in a social-media-assisted learning environment. Based on the experimental findings, students' learning motivation can be improved in the social interaction activities. Even though the learning achievement was not significantly improved, we believe there will still be possibilities based on the qualitative results. The results of questionnaire showed that high school students did not use Facebook to discuss after class, because computer science was not one of their exam subjects. Therefore, students did not spent much time joining the discussion group after school The other reasons might be that the strategy teachers used to lead discussion needed to be improved, the topic of discussion was not attractive enough to students, or students did not understand the content of lessons. In the future, we will design discussion guide strategies to make students focus on lecture topics so that they can post and compare opinions based on explicit rules, and then benefit more from social interaction.

\section{REFERENCES}

[1] S. Jacobs, C. A. Egert, and S. B. Barnes, "Social media theory and practice: lessons learned for a pioneering course," ASEE/IEEE Frontiers in Education Conference, 2009.

[2] S. He and P. Wang, "Web 2.0 and social learning in a digital economy," IEEE International Symposium on Knowledge Acquisition and Modeling, pp. 1121-1124, 2008.

[3] H. Cho, G. Gay, B. Davidson, and A. Ingraffea, "Social networks, communication styles, and learning performance in a CSCL community," Computers and Education, vol. 49, pp. 309-329, 2007.

[4] L. Moreno, C. Gonzalez, I. Castilla, E. Gonzalez, and J. Sigut, "Applying a constructivist and collaborative methodological approach in engineering education," Computers and Education, vol. 49, pp. 891-915, 2007.

[5] E. Soloway, "Learning to program = learning to construct mechanisms and explanations," Communications of the ACM, vol. 29, no. 9, pp. 850-858, 1986.

[6] P. Fadi, M. T. Deek, and J. A. McHugh, "A common model for problem solving and program development," IEEE Transactions on Education, vol. 42, pp. 331-336, 1999.

[7] P. E. Blosser, "Teaching problem solving--secondary school," ERIC Clearinghouse for Science Mathematics and Environmental Education, 1988.

[8] J. C. Yen and C. Y. Lee, "Exploring problem solving patterns and their impact on learning achievement in a blended learning environment,' Computer and Education, vol. 56, pp. 138-14, 2010.

[9] L. L. Beck and A. W. Chizhik, "An experimental study of cooperative learning in CS1," ACM Computer and Information Science Education, 2008.

[10] H. T. Hou and S. Y. Wu, "Analyzing the social knowledge construction behavioral patterns of an online synchronous collaborative discussion instructional activity using an instant messaging tool: A case study," Computer and Education, vol. 57, pp. 1459-1468, 2011.

[11] Y. Inal and K. Cagiltay, "Flow experiences of children in an interactive social game environment," British Journal of Educational Technology, vol. 38, no. 3, pp. 455-464, 2007.

[12] C. T. Sun, and S. J. Lin, "Cooperative learning through network: interactive learning environment, teaching, and assessment," Psychology press, 2007.

[13] Y. J. Lee, "Empowering teachers to create educational software: A constructivist approach utilizing Etoys, pair programming and cognitive apprenticeshop," Computers and Education, vo. 56, pp. 527-538, 2011.

[14] K. Haythommthwaite, "Characterized social networks as having the following components: Actors," New York: Nodes, 2005.

[15] J. A. Barnes, "Class and committees in a norwegian island parish," Human Relations, vol. 7, pp.39-58, 1954.

[16] J. Scott, "Social Network Analysis: A Handbook," Newbury Park, 1991. 